\title{
Correction to: Human embryonic stem cell- derived extracellular vesicles alleviate retinal degeneration by upregulating Oct4 to promote retinal Müller cell retrodifferentiation via HSP90
}

Yifeng Ke ${ }^{1 \dagger}$, Xiaoe Fan ${ }^{2 \dagger}$, Rui Hao ${ }^{3}$, Lijie Dong ${ }^{1}$, Min Xue ${ }^{4}$, Liangzhang Tan ${ }^{1}$, Chunbo Yang ${ }^{1,5}$, Xiaorong Li $^{1 *}$ and Xinjun Ren ${ }^{1 *}$

Correction to: Stem Cell Res Ther 12, 21 (2021) https://doi.org/10.1186/s13287-020-02034-6

\section{Correction}

The original article [1] contained an error in the Corresponding Authorship notation and Authors' contributions sections which have since been corrected.

\section{Author details}

${ }^{1}$ Tianjin Key Laboratory of Retinal Functions and Diseases, Tianjin International Joint Research and Development Centre of Ophthalmology and Vision Science, Eye Institute and School of Optometry, Tianjin Medica IUniversity Eye Hospital, No 251, Fukang Road, Nankai District, Tianjin 300384, People's Republic of China. 'Jincheng People's Hospital, Jincheng 048000, Shanxi, People's Republic of China. ${ }^{3}$ Tianjin Eye Hospital, Tianjin Key Laboratory of Ophthalmology and Vision Science, Nankai University Eye Hospital, Clinical College of Ophthalmology, Tianjin Medical University, Tianjin 300020, People's Republic of China. ${ }^{4}$ Department of Ophthalmology, Anhui No.2 Provincial People's Hospital, Hefei 230000, Anhui, People's Republic of China. ${ }^{5}$ Institute of Genetic Medicine, Newcastle University, Central Parkway, Newcastle upon Tyne NE1 3 BZ, UK.
Published online: 15 February 2021

\section{Reference}

1. Ke Y, et al. Human embryonic stem cell-derived extracellular vesicles alleviate retinal degeneration by upregulating Oct4 to promote retinal Müller cell retrodifferentiation via HSP90. Stem Cell Res Ther. 2021;12:21. https://doi.org/10.1186/s13287-020-02034-6.

The original article can be found online at https://doi.org/10.1186/s13287020-02034-6.

*Correspondence: Xiaor11@163.com; zlrxjrsy@126.com

${ }^{+}$Yifeng Ke and Xiaoe Fan contributed equally to this work.

${ }^{1}$ Tianjin Key Laboratory of Retinal Functions and Diseases, Tianjin

International Joint Research and Development Centre of Ophthalmology and Vision Science, Eye Institute and School of Optometry, Tianjin Medica

IUniversity Eye Hospital, No 251, Fukang Road, Nankai District, Tianjin 300384, People's Republic of China

Full list of author information is available at the end of the article

(c) The Author(s). 2021 Open Access This article is licensed under a Creative Commons Attribution 4.0 International License, which permits use, sharing, adaptation, distribution and reproduction in any medium or format, as long as you give appropriate credit to the original author(s) and the source, provide a link to the Creative Commons licence, and indicate if changes were made. The images or other third party material in this article are included in the article's Creative Commons licence, unless indicated otherwise in a credit line to the material. If material is not included in the article's Creative Commons licence and your intended use is not permitted by statutory regulation or exceeds the permitted use, you will need to obtain permission directly from the copyright holder. To view a copy of this licence, visit http://creativecommons.org/licenses/by/4.0/ The Creative Commons Public Domain Dedication waiver (http://creativecommons.org/publicdomain/zero/1.0/) applies to the data made available in this article, unless otherwise stated in a credit line to the data. 